\title{
A polysaccharide fraction extracted from Pleurotus ostreatus mycelial biomass inhibit Sarcoma 180 tumor
}

\author{
ELISABETH WISBECK ${ }^{1}$, JEAN M. FACCHINI ${ }^{1}$, ENDI P. ALVES ${ }^{1}$, MARCIA L.L. \\ SILVEIRA ${ }^{1}$, REGINA M.M. GERN ${ }^{1}$, JORGE L. NINOW ${ }^{2}$ and SANDRA A. FURLAN ${ }^{1}$ \\ ${ }^{1}$ Universidade da Região de Joinville/UNIVILLE, Campus Universitário, Zona Industrial, \\ Rua Paulo Malschitzki, 10, 89219-710 Joinville, SC, Brazil \\ ${ }^{2}$ Universidade Federal de Santa Catarina/UFSC, Campus Universitário, Trindade, 88040-900 Florianópolis, SC, Brazil
}

Manuscript received on October 8, 2015; accepted for publication on March 18, 2016

\begin{abstract}
Fungi of Pleurotus genus have attracted a great interest due to their medicinal properties such as antiinflammatory, antimicrobial and antitumor. These properties are attributed mainly to polysaccharides synthesized by Pleurotus. This work aimed to study the mycelial growth of P. ostreatus in submerged culture, evaluating the influence of the initial concentration of substrate (20 and $40 \mathrm{~g} / \mathrm{L}$ of glucose) and the $\mathrm{pH}$ (4 and 6) on kinetic parameters of production of biomass. The effectiveness of different doses $(10,30$ and $50 \mathrm{mg} / \mathrm{kg})$ of a mycelium polysaccharide fraction extracted from $P$. ostreatus in reducing Sarcoma 180 development in mice was also verified. In the range of this study, maximum concentration of mycelial biomass (about $12.8 \mathrm{~g} / \mathrm{L}$ ) was obtained using $40.0 \mathrm{~g} / \mathrm{L}$ of glucose, at $\mathrm{pH} 4.0$. The total biomass productivity $(\mathrm{Px})$ was not significantly affected by substrate concentration and $\mathrm{pH}$, reaching values of 0.034 g/L.h. Sarcoma 180 tumor weight was reduced in $74.1,75.5$ and $53.7 \%$ when 10,30 and $50 \mathrm{mg} / \mathrm{kg}$ were administered, respectively. These results show the high antitumor potential of intracellular polysaccharide fraction of mycelial biomass of $P$. ostreatus, particularly at lower doses of 10 and $30 \mathrm{mg} / \mathrm{kg}$.
\end{abstract}

Key words: Antitumor Activity, Mycelium, Pleurotus ostreatus, Polysaccharides, Sarcoma 180.

\section{INTRODUCTION}

Fungi of the class of basidiomycetes are well known for producing a great number of bioactive molecules (Wasser 2002, Lindequist et al. 2005). Among the basidiomycetes, the genus Pleurotus has been intensively studied due to its antitumor activity ( $\mathrm{Xu}$ et al. 2012). The increase of the number of these studies is related to the search

Correspondence to: Regina Maria Miranda Gern

E-mail: regina.maria@univille.br of new and natural molecules that can act against tumor cells without the collateral effects associated to the conventional therapies that involve chemical and physical agents producing side effects or toxic reactions (Bast et al. 2000). According to Liu (2004), epidemiological and preclinical tests have demonstrated the great potential of natural products in combating cancer and other chronic diseases that result from oxidative stress.

Among the several molecules with bioactivity produced by fungi, polysaccharides seems to be the 
main responsible by the antitumor effect (Ren et al. 2012). Regarding the genus Pleurotus, several polysaccharidic extracts from the fruiting bodies with antitumor activity have been reported (Liu et al. 2015, Assis et al. 2013, Patel et al. 2012), although a few reports are found describing the mycelium antitumor effect.

Depending on the fungi culture conditions (submerged or solid culture, $\mathrm{pH}$, temperature, oxygen concentration, composition of the culture medium etc) and of the method of extraction, polysaccharides with different structures and, consequently, different bioactivities can be obtained from the fruiting bodies, from the fermented culture broth or from the mycelial biomass (Zhang et al. 2007, Synytsya and Novák 2013, Ruthes et al. 2015). Silveira et al. (2015) reported a mannogalactan with antinociceptive and antiinflammatory effects extracted from the culture broth of Pleurotus sajor-caju by freeze-thawing and dialysis. A $(1 \rightarrow 3)$ - $\beta$-D-glucan with antiinflammatory activity was isolated from fruiting bodies of Pleurotus sajor-caju via extraction with hot water followed by fractionation by freezethawing and finally by dimethyl sulfoxide extraction (Silveira et al. 2014). Komura et al. (2014) isolated a water-soluble mannogalactan from Pleurotus ostreatus var. florida mycelial biomass concluding that is possible to obtain similar and also different molecules from those found in the fruiting body and mycelial biomass of the same mushroom species.

The factorial design has been widely applied in optimization of medium composition (Gern et al. 2008, Papaspyridi et al. 2010) replacing the classical or empirical methods such as one-factorat-a-time-method, which is time consuming process and incapable of searching the global optimal condition, especially when interaction between independent factors exists (Papaspyridi et al. 2010). This work studied the mycelial growth of Pleurotus ostreatus DSM 1833 in submerged culture, using a factorial design to evaluate the effect of the initial concentration of glucose and the medium $\mathrm{pH}$ over the kinetic parameters of the process. In addition, further experiments were conducted to verify the efficacy of different doses of a polysaccharidic fraction extracted from the mycelium biomass, on the inhibition of Sarcoma 180 induced in mice.

\section{MATERIALS AND METHODS}

Pleurotus ostreatus DSM 1833 obtained from Deutsche Sammlung von Mikroorganismen und Zellkulturen Gmbh, German, was maintained in WDA (Wheat-Dextrose-Agar) solid medium composed by $20 \mathrm{~g}$ of glucose, $15 \mathrm{~g}$ of agar and $1 \mathrm{~L}$ of wheat extract (Furlan et al. 1997). Inoculum was produced in Duran flask of $2 \mathrm{~L}$ containing $400 \mathrm{~mL}$ of POL medium (Cavazzoni and Adami 1992) with the following composition $(\mathrm{g} / \mathrm{L})$ : glucose, 20.0; $\left(\mathrm{NH}_{4}\right)_{2} \mathrm{SO}_{4}, 5.0 ; \mathrm{MgSO}_{4} .7 \mathrm{H}_{2} \mathrm{O}, 0.2 ; \mathrm{K}_{2} \mathrm{HPO}_{4}, 1.0$; yeast extract, 2.0 and peptone, $1.0 ; \mathrm{pH} 6.5-7.0$. The flask was inoculated with the whole mycelium of a 7-day-old culture grown in a Petri dish, and incubated at $30^{\circ} \mathrm{C}, 120 \mathrm{~min}^{-1}$ (reciprocal), for 6 days.

Cultivation was carried out in a Biostat B (B. BRAUN) bioreactor containing $4 \mathrm{~L}$ of POL medium described above added with $1.0 \mathrm{~g} / \mathrm{L}$ of $\mathrm{CaCO}_{3}$, inoculated with $400 \mathrm{ml}$ of inoculum and incubated at $30^{\circ} \mathrm{C}$. Initial $\mathrm{K}_{\mathrm{L}}$ a of $15 \mathrm{~h}^{-1}$ was achieved under agitation of $300 \mathrm{~min}^{-1}$ and $0.25 \mathrm{~L} / \mathrm{min}$ of air supply. The initial concentration of glucose and the $\mathrm{pH}$ varied according to the $2^{2}$ factorial design shown in Table I. Experiments were carried out in duplicate. Pareto Analysis (Barros Neto et al. 1995) was used to estimate the effects of each variable and their interactions on the response parameters.

Mycelial biomass was measured by gravimetry. Samples were filtered in Whatman no. 1, washed, transferred to pre-weighed crucibles, and dried for $48 \mathrm{~h}$, at $90^{\circ} \mathrm{C}$. Biomass concentration was reported as the dry weight of biomass per volume of sample. Determination of glucose concentration was 
TABLE I

Factorial design $2^{2}$ varying the initial glucose concentration and the medium $\mathbf{p H}$. Symbols (-) and (+) represent inferior and superior levels, respectively.

\begin{tabular}{ccc}
\hline Variables & \multicolumn{3}{c}{ Levels } \\
\hline $\mathrm{pH}$ & - & + \\
Glucose $(\mathrm{g} / \mathrm{L})$ & 4 & 6 \\
\hline
\end{tabular}

performed using the enzymatic method of glucose oxidase-peroxidase (Glicose-E, CELM, Brasil).

Mycelial biomass resulting from the best condition obtained from the factorial design was removed from the culture broth by vacuum filtration using Whatmann no. 1. The biomass was washed with distilled water, frozen, and fractionated according to the methodology proposed by Zhang et al. (1994), modified by Dalonso et al. (2010). Briefly, 2 volumes of ethanol were added to the frozen mycelial biomass and the suspension was maintained at $80^{\circ} \mathrm{C}$ for $3 \mathrm{~h}$. The mixture was centrifuged $(3.400 \mathrm{~g})$ and the supernatant containing low molecular weight molecules was discarded. This procedure was repeated 4 times. The solid residue "S" generated was boiled in water for $3 \mathrm{~h}$ and filtered. This procedure was repeated 4 times. The new residue obtained (Residue I) was mixed with $1 \%$ solution of $\mathrm{NH}_{4}$-oxalate, boiled for $3 \mathrm{~h}$ and filtered. This procedure was repeated 4 times and aimed to extract polysaccharides from Residue I. Five volumes of ethanol was added to the filtrate and the mixture was maintained at $4^{\circ} \mathrm{C}$ for about 24 $\mathrm{h}$ and centrifuged (3.400 g). The supernatant was discarded, and the solid residue containing mainly polysaccharides (Precipitate II) was lyophilized and named FII (Facchini et al. 2014).

FII fraction was administered in doses of 10,30 and $50 \mathrm{mg} / \mathrm{kg}$ in male Swiss mice (Mus musculus) weighing $30 \pm 5 \mathrm{~g}$, purchased from the Instituto Tecnológico do Paraná - TECPAR, Curitiba/PR/Brazil. Animals were divided into 4 groups according to Table II. The fraction was solubilized in phosphate buffer (PBS) $0.01 \mathrm{M}, \mathrm{pH}$
7.0 at concentrations of $1 \mathrm{~g} / \mathrm{L}$ (for the dose of 10 $\mathrm{mg} / \mathrm{kg}$ ) and $10 \mathrm{~g} / \mathrm{L}$ (for the doses of 30 and $50 \mathrm{mg} /$ $\mathrm{kg}$ ). The treatment was performed intraperitoneally (ip) for 10 days (Zhang et al. 1994), starting $24 \mathrm{~h}$ after the induction of the tumor by the inoculation of S-180 in the ascitic form ( $5 \times 10^{6}$ cells/animals) subcutaneously on the back of each mouse of the positive and control groups (Nakamura et al. 2004).

The assessment of tumor development was performed 21 days after tumor induction (Harhaji et al. 2008) by determining the weight ( $\mathrm{g}$ ) of the tumor according to Misaki et al. (1984) and the rate of tumor inhibition (I\%) (Mizuno 1999), calculated according to the Equation 1.

$I(\%)=\frac{C-T}{C} * 100$

Where:

$\mathrm{C}=$ weight of the tumor of the Positive Control Group (g)

$\mathrm{T}=$ weight of the tumor of the Test Group $(\mathrm{g})$.

Data were evaluated by Dixon's "Q" test for rejection of deviant values at the $95 \%$ confidence level (Rorabacher 1991) and by Tukey test for analysis of variance of the mean values (ANOVA), with significance level of $5 \%(\mathrm{p}<0.05)$.

All the procedures were approved by the Ethics Committee on Research with Animals of the University of Joinville Region and are in

TABLE II

Distribution of the animals according to the experiment.

\begin{tabular}{cccc}
\hline Group & Treatment & $\begin{array}{c}\text { Dose } \\
(\mathbf{m g} / \mathbf{k g})\end{array}$ & $\begin{array}{c}\text { No. of } \\
\text { animals }\end{array}$ \\
\hline Test (TG) & $\begin{array}{c}\text { Tumor induction and } \\
\text { administration of FII }\end{array}$ & $\begin{array}{c}10,30 \\
\text { and } 50\end{array}$ & 10 \\
$\begin{array}{c}\text { Substance } \\
\text { Control } \\
\text { (SC) }\end{array}$ & $\begin{array}{c}\text { Administration of FII } \\
\text { without tumor induction }\end{array}$ & $\begin{array}{c}10,30 \\
\text { and } 50\end{array}$ & 10 \\
$\begin{array}{c}\text { Positive } \\
\text { Control } \\
\text { (PC) }\end{array}$ & $\begin{array}{c}\text { Tumor induction and } \\
\text { administration of PBS }\end{array}$ & 10 & 10 \\
$\begin{array}{c}\text { Negative } \\
\text { Control } \\
\text { (NC) }\end{array}$ & $\begin{array}{c}\text { Administration of PBS } \\
\text { without tumor induction }\end{array}$ & 10 & 10 \\
\hline
\end{tabular}


accordance with the $E U$ Directive 2010/63/EU for animal experiments.

\section{RESULTS}

Figure 1 shows the profiles of mycelial biomass (X) and glucose concentrations (S) with time.

Data extracted from Figure 1 allowed the construction of Table III. Table IV shows the effects of glucose and $\mathrm{pH}$ on the mycelia biomass concentration $(\Delta X)$, overall yield of glucose on mycelial biomass $\left(\mathrm{Y}_{\mathrm{X} / \mathrm{s}}\right)$ and overall mycelial biomass productivity $(\mathrm{Px})$. The effects shown on Table IV are considered significant only when their absolute values are higher than the correspondent absolute value statistically significant (AVSS). A negative and a positive effects express that the value of the variable increases towards the inferior and superior levels, respectively.

Evaluation of the antitumor effect of fraction FII was carried out through a dose $\mathrm{x}$ response assay, using 10, 30 and $50 \mathrm{mg} / \mathrm{kg}$. The results of tumor weight $(\mathrm{g})$ and tumor inhibition rate $(\mathrm{I} \%)$ are shown in Figure 2. Doses of 10 and $30 \mathrm{mg} / \mathrm{kg}$ promoted the highest inhibition rate, of about $75 \%$, without significant differences between them. The dose of $50 \mathrm{mg} / \mathrm{kg}$ promoted the lowest inhibition rate $(53.7 \%)$.

\section{DISCUSSION}

Glucose uptake is faster in $\mathrm{pH} 6.0$ (experiments 2 and 4) than in $\mathrm{pH} 4.0$ (experiments 1 and 3 ) for the same initial glucose concentration (Figure 1). However, $\mathrm{pH} 4.0$ led to higher values of biomass, showing

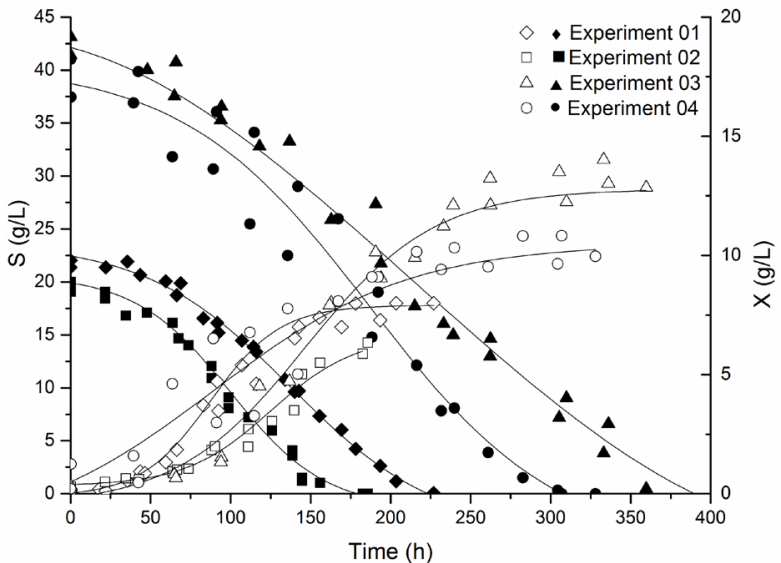

Figure 1 - Kinetic profile of mycelial biomass concentration $(\mathrm{X})$ and substrate (glucose) concentration $(\mathrm{S})$ obtained for the experiments $01(\diamond, \bullet), 02(\square, \boldsymbol{\bullet}), 03(\Delta, \boldsymbol{\Delta})$ and $04(\circ, \bullet)$. Open and closed symbols represent $\mathrm{X}$ and $\mathrm{S}$, respectively.

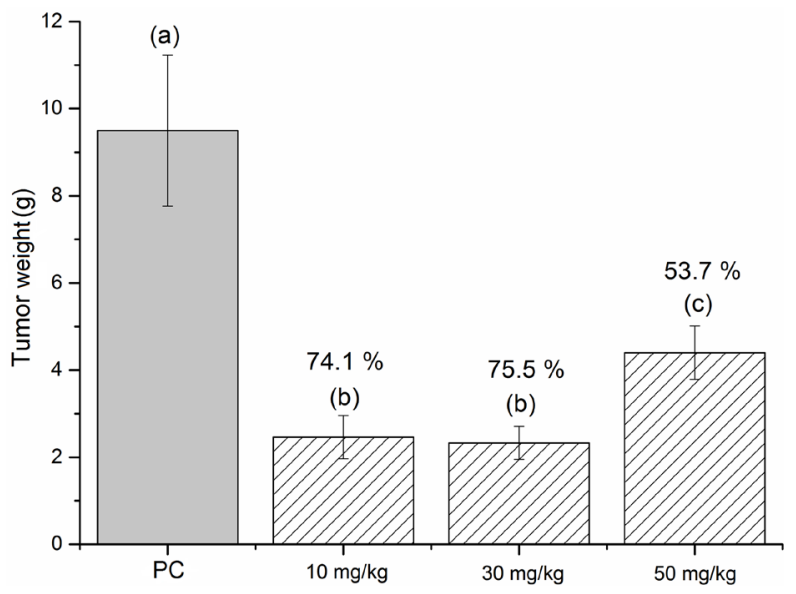

Figure 2 - Tumor weight and tumor inhibition rate (\%) of Sarcoma 180 after 21 days of mice treatment with 10, 30 and $50 \mathrm{mg} / \mathrm{kg}$ of FII fraction extracted from mycelial biomass of Pleurotus ostreatus. Bars indicate mean values \pm standard error. Equal letters indicate values without significant differences according to the Tukey test, at a confidence level of $95 \%$. PC $=$ Positive Control group.

TABLE III

Mean values \pm standard deviation of $\Delta X$ (mycelial biomass concentration), $Y_{x / s}$ (overall yield of glucose on mycelial biomass) and Px (overall mycelial biomass productivity).

\begin{tabular}{cccccc}
\hline Experiment & Glucose $(\mathbf{g} / \mathbf{L})$ & $\mathbf{p H}$ & $\Delta \mathbf{X}(\mathbf{g} / \mathbf{L})$ & $\mathbf{Y}_{\mathbf{X} / \mathbf{s}}(\mathbf{g} / \mathbf{g})$ & $\mathbf{P x}(\mathbf{g} / \mathbf{L} . \mathbf{h})$ \\
\hline 01 & 20 & 4 & $7.53 \pm 0.41$ & $0.37 \pm 0.03$ & $0.035 \pm 0.002$ \\
02 & 20 & 6 & $5.81 \pm 0.29$ & $0.30 \pm 0.02$ & $0.031 \pm 0.001$ \\
03 & 40 & 4 & $12.86 \pm 0.83$ & $0.32 \pm 0.03$ & $0.037 \pm 0.004$ \\
04 & 40 & 6 & $9.65 \pm 1.29$ & $0.25 \pm 0.03$ & $0.030 \pm 0.005$ \\
\hline
\end{tabular}


TABLE IV

Effects of the variables glucose $(\mathrm{g} / \mathrm{L})$ and $\mathrm{pH}$ on the mycelia biomass concentration $(\Delta \mathrm{X})$, overall yield of glucose on mycelial biomass $\left(\mathrm{Y}_{\mathrm{x} / \mathrm{s}}\right)$ and overall mycelial biomass productivity $(\mathrm{Px})$.

\begin{tabular}{cccc}
\hline \multirow{2}{*}{ Variables } & \multicolumn{3}{c}{ Estimated effects \pm standard error } \\
\cline { 2 - 4 } & $\Delta \mathbf{X}(\mathbf{g} / \mathbf{L})$ & $\mathbf{Y}_{\mathbf{X} / \mathbf{S}}(\mathbf{g} / \mathbf{g})$ & $\mathbf{P x}(\mathbf{g} / \mathbf{L} . \mathbf{h})$ \\
\hline glucose & $4.589 \pm 0.57^{*}$ & $-0.0049 \pm 0.02$ & $0.00025 \pm 0.0024$ \\
$\mathrm{pH}$ & $-2.462 \pm 0.57^{*}$ & $-0.0715 \pm 0.02 *$ & $-0.00525 \pm 0.0024$ \\
Interaction glucose and $\mathrm{pH}$ & $-0.747 \pm 0.57$ & $0.0035 \pm 0.02$ & $-0.00125 \pm 0.0024$ \\
AVSS $^{* *}$ & $|1.58|$ & $|0.056|$ & $|0.0068|$ \\
\hline
\end{tabular}

*Statistically significant values at confidence limits of $95 \%$.** Absolute value statistically significant.

the negative effect of the $\mathrm{pH}$ over the mycelial biomass concentration $(\mathrm{X})$ and on the overall yield of glucose on mycelial biomass $\left(\mathrm{Y}_{\mathrm{X} / \mathrm{S}}\right.$ ) (Table IV). The overall mycelial biomass productivity (Px) was not significantly affected by the $\mathrm{pH}$ or by the initial glucose concentration (Table IV). Despite the increase of $70 \%$ in the cultivation time when initial concentration of glucose increases from 20.0 to $40.0 \mathrm{~g} / \mathrm{L}$, the increase in mycelial biomass is proportional (Figure 1, Table III). Experiment 3 $(40.0 \mathrm{~g} / \mathrm{L}$ of glucose and $\mathrm{pH} 4.0)$ led to an overall mycelial biomass productivity of $0.037 \mathrm{~g} / \mathrm{L}$.h. This result is higher than those reported by Borges et al. (2013) (0.022 g/L.h), cultivating P. djamor using the same medium, at $\mathrm{pH} 4.0$ and $40 \mathrm{~g} / \mathrm{L}$ of initial glucose concentration. Gern et al. (2008), cultivating $P$. ostreatus in a medium containing corn steep liquor as nitrogen source, $40.0 \mathrm{~g} / \mathrm{L}$ of initial glucose concentration and $\mathrm{pH} 4.0$, reach lower values of maximum productivity, achieved in 6 days of cultivation $(0.032 \mathrm{~g} / \mathrm{L}$.h).

The effect of the initial concentration of glucose was only significant (positive effect) for the concentration of mycelial biomass (X) (Table IV). The same behavior was observed by Burns et al. (1994) for Pleurotus sp. florida. In this case, the increase in the initial glucose concentration led to the increase of biomass $(9.7 \mathrm{~g} / \mathrm{L}$ of biomass after 17 days, using $20 \mathrm{~g} / \mathrm{L}$ of initial glucose and $\mathrm{pH} 4.0$ ). Confortin etal. (2008) evaluated glucose and sucrose as carbon sources for $P$. sajor-caju, achieving 8.18 and $5.94 \mathrm{~g} / \mathrm{L}$ of mycelial biomass using $10 \mathrm{~g} / \mathrm{L}$ of glucose and $10 \mathrm{~g} / \mathrm{L}$ of sucrose, respectively. Assis et al. (2013), working with $20 \mathrm{~g} / \mathrm{L}$ of glucose and $\mathrm{pH}$ 4.0 reached $5.7 \mathrm{~g} / \mathrm{L}$ of mycelial biomass of $P$. sajorcaju. Borges et al. (2013), cultivating $P$. djamor using $40 \mathrm{~g} / \mathrm{L}$ of glucose and $\mathrm{pH} 4.0$ reached 6.28 $\mathrm{g} / \mathrm{L}$ of biomass in 13 days. Higher value of biomass $(12.9 \mathrm{~g} / \mathrm{L})$ was observed in our work (experiment 3 , Table III), achieved in 14 days of cultivation. Thus, this condition $(40.0 \mathrm{~g} / \mathrm{L}$ of initial glucose concentration and $\mathrm{pH} 4.0$ ) was chosen to produce biomass aiming the extraction of FII fraction. Biomass was separated from the culture broth by filtration, washed with distilled water, and frozen.

Tao et al. (2006) evaluated the antitumor action of several polysaccharides fractions of Pleurotus tuber-regium fruiting bodies against Sarcoma 180 in mice. Animals were treated with daily doses of 20 and $60 \mathrm{mg} / \mathrm{kg}$, during 8 days. After 8 days, the highest tumor inhibition rate was obtained with 60 $\mathrm{mg} / \mathrm{kg}$ of FII fraction (72.1\%). The same fraction, at a dose of $20 \mathrm{mg} / \mathrm{kg}$, has led to only $21.6 \%$ of the inhibition of tumor development. These results are not in agreement with those shown in Figure 2 , in which the increase of the dose from 30 for 50 $\mathrm{mg} / \mathrm{kg}$ promoted a decrease of $22 \%$ in the tumor inhibition rate. Moreover, results obtained with the doses of 10 and $30 \mathrm{mg} / \mathrm{kg}$ shown in our work are higher than those reported by Tao et al. (2006) with a higher dose $(60 \mathrm{mg} / \mathrm{kg})$. The difference is probably due to the species of Pleurotus. Other authors also observed that highest doses promoted the decrease in tumor inhibition. Jeong et al. 
(2010) evaluated a polysaccharide fraction from mycelial biomass of $P$. eryngii against Sarcoma 180. Extraction was carried out in hot water and the supernatant free of biomass was treated with four volumes of ethanol for precipitation of polysaccharides. Animals were treated with 10 to $80 \mathrm{mg} / \mathrm{kg}$ of mycelial extract, during 28 days. 40 $\mathrm{mg} / \mathrm{kg}$ promoted the highest tumor inhibition rate (53.1\%) while $80 \mathrm{mg} / \mathrm{kg}$ inhibited tumor weight in only $25.7 \%$. In our work, the dose of $50 \mathrm{mg} /$ $\mathrm{kg}$ of FII fraction promoted $53.7 \%$ of inhibition, similar to the results obtained by Jeong et al. (2010) using $40 \mathrm{mg} / \mathrm{kg}$. De Barba et al. (2011) evaluated the antitumor effect of different doses (10, 30 and $100 \mathrm{mg} / \mathrm{kg}$ ) of an ethanolic precipitated from the culture broth of Pleurotus djamor, against Sarcoma 180 in mice. The authors observed that $30 \mathrm{mg} / \mathrm{kg}$ promoted the highest tumor inhibition (94\%) and that the increase of the dose to $100 \mathrm{mg} / \mathrm{kg}$ led to a reduction of $30 \%$ in the inhibition rate. Assis et al. (2013) found an inhibition rate of Sarcoma 180 of about $84 \%$ using doses of 10,30 and $100 \mathrm{mg} / \mathrm{kg}$ of an ethanolic precipitated from the culture broth of $P$. sajor-caju indicating that the tumor effect was not dose dependent.

According to Wasser (2002), bioactivity of polysaccharides can be associated to several factors such as water solubility, molecular weight, structure and linkage, among others, making difficult the correlation between structure and biological activity of the complex polysaccharides. Zhang et al. (1994) performed the characterization of the monosaccharide composition of extractive fractions obtained from dried fruiting bodies of P. citrinopileatus. The fraction FII, similar to the FII fraction studied in our work, showed $83.5 \%$ of monosaccharide as glucose, fucose, mannose and galactose, and $16.5 \%$ of proteins. Zhang et al. (2007) reported that in some mushrooms species, the polysaccharides are linked to proteins or peptides, conferring high antitumor potential to the molecule. The authors also reported that the discovery of human macrophages receptors with high specificity for glucose and mannose could confer high antitumor effect to polysaccharides that contain these monomers. Structural features such as $\beta$ - $(1 \rightarrow 3)$ bonds in the main chain of the polymer, and $\beta$ - $(1 \rightarrow 6)$ branches are also important factors for antitumor activity.

In the range of our study for the production of $P$. ostreatus mycelial biomass (20 and $40 \mathrm{~g} / \mathrm{L}$ of initial glucose; $\mathrm{pH} 4.0$ and 6.0), $\mathrm{pH} 4.0$ and $40 \mathrm{~g} / \mathrm{L}$ of glucose promoted the highest biomass concentration $(12.8 \mathrm{~g} / \mathrm{L})$. The FII fraction obtained from frozen mycelium of $P$. ostreatus reduced about $75 \%$ Sarcoma 180 tumor weight after 10 days of administration at the doses of 10 and 30 $\mathrm{mg} / \mathrm{kg}$ in mice. This suggests that low doses of FII fraction can act as antitumor, being promising as antineoplastic.

\section{ACKNOWLEDGMENTS}

The authors thank to Fundação de Amparo à Pesquisa e Inovação do Estado de Santa Catarina (FAPESC) and UNIVILLE for the financial support.

\section{REFERENCES}

ASSIS IS, BONATTI-CHAVES M, SILVEIRA MLL, GERN RMM, WISBECK E, FÚRIGO JÚNIOR A AND FURLAN SA. 2013. Production of bioactive compounds with antitumour activity against Sarcoma 180 by Pleurotus sajor-caju. J Med Food 16: 1004-1012.

BARROS NETO B, SCARMINIO IS AND BRUNS RE. 1995. Planejamento e otimização de experimentos, $2^{\text {nd }}$ ed., Campinas: Editora da Unicamp, 299 p.

BAST RC, KUFE DW, POLLOCK RE, WEICHSELBAUM RR, HOLLAND JF AND FREI E. 2000. Holland-Frei Cancer Medicine, $5^{\text {th }}$ ed., Hamilton: B C Decker Inc., Chapter 76.

BORGES GM, SCHIEBELBEINAP, BARBAFFM, PEREIRA BP, CHAVES MB, SILVEIRA MLL, PINHO MSL, FURLAN SA AND WISBECK E. 2013. Extracellular polysaccharide production by a strain of Pleurotus djamor isolated in the south of Brazil and antitumor activity on Sarcoma 180. Braz J Microbiol 44: 1059-1065. 
BURNS PJ, YEO P, KESHAVARZ T, ROLLER S AND EVANS CS. 1994. Physiological studies of exopolysaccharide production from the Basidiomycete Pleurotus sp. florida. Enzyme Microb Technol 34: 566-572.

CAVAZZONI V AND ADAMI A. 1992. Exopolysaccharides produced by mycelial edible mushrooms. Ital J Food Sci 1: 9-15.

CONFORTIN FG, MARCHETTO R, BETTIN F, CAMASSOLA M, SALVADOR M AND DILLON AJP. 2008. Production of Pleurotus sajor-caju strain PS-2001 biomass in submerged culture. J Ind Microbiol Biotechnol 35: $1149-1155$.

DALONSO N, SOUZA R, SILVEIRA MLL, RUZZA AA, WAGNER TM, WISBECK E AND FURLAN SA. 2010. Characterization and antineoplasic effect of extracts obtained from Pleurotus sajor-caju fruiting bodies. Appl Biochem Biotechnol 160: 2265-2274.

DE BARBA FFM, SILVEIRA MLL, PILONI BU, FURLAN SA AND PINHO MSL. 2011. Influence of Pleurotus djamor bioactive substances on the survival time of mice inoculated with Sarcoma 180. Int J Pharm 7: 478-484.

FACCHINI FM, WISBECK E, ALVES EP, AGUILERA C, GERN RMM, SILVEIRA MLL AND FURLAN SA. 2014. Antitumor activity of Pleurotus ostreatus polysaccharide fractions on Ehrlich tumor and Sarcoma 180. Int J Biol Macromol 68: 72-77.

FURLAN SA, VIRMOND LJ, MIERS DA, BONATTI M, GERN RMM AND JONAS R. 1997. Mushrooms strains able to grow at high temperatures and low $\mathrm{pH}$ values. World J Microbiol Biotechnol 13: 689-692.

GERN RM, WISBECK E, RAMPINELLI J, NINOW JL AND FURLAN SA. 2008. Alternative medium for production of Pleurotus ostreatus biomass and potential antitumor polysaccharides. Bioresour Technol 99: 76-82.

HARHAJI LJ ET AL. 2008. Anti-tumor effect of Coriolus versicolor methanol extract against mouse B16 melanoma cells: in vitro and in vivo study. Food Chem Toxicol 46: 1825-1833.

JEONG YT, JEONG SC, GU YA, ISLAM R AND SONG CH. 2010. Antitumor and immunomodulating activities of endo-biopolymers obtained from a submerged culture of Pleurotus eryngii. Food Sci Biotechnol 19: 399-404.

KOMURA DL, RUTHES AC, CARBONERO ER, GORIN PAJ AND IACOMINI M. 2014. Water-soluble polysaccharides from Pleurotus ostreatus var. florida mycelial biomass. Int J Biol Macromol 70: 354-359.

LINDEQUIST U, NIEDERMEYER THJ AND JULICH WD. 2005. The pharmacological potential of mushroom. Evid Based Complement Alternat Med 2: 285-299.

LIU RH. 2004. Potential synergy of phytochemicals in cancer prevention: mechanism of action. J Nutr 134: $3479 \mathrm{~S}-3485 \mathrm{~S}$.
LIU X, WANG L, ZHANG C, WANG H, ZHANG X AND LI Y. 2015. Structure characterization and antitumor activity of a polysaccharide from the alkaline extract of king oyster mushroom. Carbohydr Polym 118: 101-106.

MISAKI A, KAWAGUCHI K, MIYAJI H, NAGAE H, HOKKOKUS S, KAKUTA M AND SASAKI T. 1984. Structure of pestalotan, a highly branched (1----3)-beta-Dglucan elaborated by Pestalotia sp. 815, and the enhancement of its antitumor activity by polyol modification of the side chains. Carbohydr Res 129: 209-227.

MIZUNO T. 1999. The extraction and development of antitumor active polysaccharides from medicinal mushrooms in Japan. Int J Med Mushrooms 1: 9-29.

NAKAMURA T, MATSUGO S, UZUKA Y, MATSUO S AND KAWAGOSJO H. 2004. Fractionation and antitumor activity of the mycelia of liquid-cultured Phelinus linteus. Biosci Biotechnol Biochem 68: 868-872.

PAPASPYRIDI LM, KATAPODIS P, GONOU-ZAGOU Z, KAPSANAKI-GOTSI E AND CHRISTAKOPOULOS P. 2010. Optimization of biomass production with enhanced glucan and dietary fibres content by Pleurotus ostreatus ATHUM 4438 under submerged culture. Biochem Eng J 50: 131-138.

PATEL Y, NARAIAN R AND SINGH VK. 2012. Medicinal Properties of Pleurotus Species (Oyster Mushroom): A Review. WJFPB 3: 1-12.

REN L, PERERA C AND HEMAR Y. 2012. Antitumor activity of mushroom polysaccharides: a review. Food Funct 3: 1118-1130.

RORABACHER DB. 1991. Statistical treatment for rejection of deviant values: critical values of Dixon's “Q” parameter and related subrange ratios at the $95 \%$ confidence level. Anal Chem 63: 139-146.

RUTHES AC, SMIDERLE FR AND IACOMINI M. 2015. D-glucans from edible mushrooms: a review on the extraction, purification and chemical characterization approaches. Carbohydr Polym 117: 753-761.

SILVEIRA MLL ET AL. 2015. Exopolysaccharide produced by Pleurotus sajor-caju: its chemical structure and antiinflammatory activity. Int J Biol Macromol 75: 90-96.

SILVEIRA MLL ET AL. 2014. Structural characterization and anti-inflammatory activity of a linear $\beta$-D-glucan isolated from Pleurotus sajor-caju. Carbohydr Polym 113: 588596.

SYNYTSYAA AND NOVÁK M. 2013. Structural diversity of fungal glucans. Carbohydr Polym 92: 792-809.

TAOY,ZHANGLANDCHEUNGPCK. 2006. Physicochemical properties and antitumor activities of water-soluble native and sulfated hyperbranched mushroom polysaccharides. Carbohydr Res 341: 2261-2269.

WASSER SP. 2002. Medicinal mushrooms as a source of anti-tumor and immunomodulating polysaccharides. Appl Microbiol Biotechnol 60: 258-274. 
XU T, BEELMAN RB AND LAMBERT JD. 2012. The cancer preventive effects of edible mushrooms. Anticancer Agents Med Chem 2: 1255-1263.

ZHANG J, WANG G, LI H, ZHUANG C, MIZUNO T, ITO H, SUZUKI C, OKAMOTO H AND LI J. 1994. Antitumor polysaccharides from a Chinese mushroom, "yuhuangmo," the fruiting body of Pleurotus citrinopileatus Biosci Biotechnol Biochem 58: 1195-1201.

ZHANG M, CUI SW, CHEUNG PCK AND WANG Q. 2007. Antitumor polysaccharides from mushrooms: a review on their isolation process, structural characteristics and antitumor activity. Trends Food Sci Technol 18: 4-19. 